\title{
Longevity and health expectancy in an ageing society: implications for public health in Italy
}

\author{
Marianna Noale $^{(\mathrm{a})}$, Federica Limongi ${ }^{(\mathrm{a})}$, Emanuele Scafato ${ }^{(\mathrm{b})}$, \\ Stefania Maggi ${ }^{(a)}$ and Gaetano Crepaldi ${ }^{(a)}$ \\ (a) Istituto di Neuroscienze, Consiglio Nazionale delle Ricerche, Sezione Invecchiamento, Padova, Italy \\ (b) Centro Nazionale per l'Epidemiologia, la Sorveglianza e la Promozione della Salute, Istituto \\ Superiore di Sanità, Rome, Italy
}

\begin{abstract}
Summary. Introduction. While the prolongation of life expectancy is due to medical, economic, social and public health advancements, longevity may not necessarily be an indicator of real development. Epidemiologic data indicate, in fact, that advanced age carries the risk of multiple diseases, disability and loss of autonomy. Materials and methods. How the years gained are lived need to be assessed evaluating quality of life, health status, and disability. Results and conclusions. Good health care planning should aim to ensure that the years of life gained are lived in good health conditions in the light of the World Health Organization's declaration that "increased longevity without quality of life is an empty prize. Health expectancy is more important than life expectancy".
\end{abstract}

Key words: demographic ageing, life expectancy, disability-free life expectancy, health planning.

Riassunto (Speranza di vita e indicatori di speranza di vita in buona salute in una società che invecchia: implicazioni per la sanità pubblica in Italia). Introduzione. L'allungamento della speranza di vita è il risultato di progressi in campo medico, economico, sociale e nel settore della salute pubblica; tuttavia, la longevità può non essere necessariamente un indicatore di sviluppo effettivo: i dati epidemiologici dimostrano che l'età avanzata comporta il rischio di essere colpiti da polipatologia, di divenire disabili e perdere la propria autonomia. Materiali e metodi. È necessario misurare come vengono vissuti gli anni di vita guadagnati, valutando cioè la qualità della vita, lo stato di salute e la disabilità negli anziani. Risultati e conclusioni. Una buona programmazione sanitaria dovrebbe puntare a garantire che gli anni di vita guadagnati siano anche vissuti in buone condizioni di salute, alla luce della dichiarazione dell'Organizzazione Mondiale della Sanità "una maggior longevità senza miglioramento della qualità di vità è un premio vuoto. La speranza di vita in buona salute è più importante della sola speranza di vita".

Parole chiave: invecchiamento demografico, speranza di vita, speranza di vita libera da disabilità, programmazione sanitaria.

\section{INTRODUCTION}

Population ageing is a demographic phenomenon with important economic, social and cultural consequences. In view of changing health and social services needs, assessment studies geared toward policy and services planning are warranted. The contraction of the working sector of the population is an important consideration as it leads to limited resources. The aim of assessment studies should be then that of addressing the needs of an ageing population in order to adequately plan for the future of an ageing society.

\section{DEMOGRAPHIC AGEING}

Demographic ageing is a function of three important factors: fertility, mortality and migratory flows [1]. When the birth rate is low, the bottom of the "age pyramid" becomes narrow reducing the number of young people in the general population. Baby boom years initially make the population younger but in the long run lead to rises in the percentage of older people in the population. Low death rates and variations in causes of death result in a shift in mortality in the oldest age groups and thus an ageing of the population at the top of the "age pyramid." Finally, depending upon the age groups of those who are immigrating and emigrating, migratory flows also influence ageing. While they can rejuvenate age groups over a brief period of time, in the long run they can lead to an increase in the elderly population.

The phenomenon of demographic ageing began in the 1930s in Italy when, thanks to better hygienic conditions, there was a decline in perinatal mortality. This was followed in the 1940s and '50s by an increase in life expectancy in children and young adults, in gen- 
eral probably due to anti-infective drug development. In the 1960s and '70s an important lengthening of life expectancy was registered in persons over 65 thanks to a general improvement in living conditions [2].

The Italian population has roughly doubled since its unification going from 26 million inhabitants in 1861 to 60626442 inhabitants in 2011 (the resident population on January 1, 2011) [3]. The population rose steadily after the ' 70 s, was stable during the '80s and '90s, and then began to grow again especially as a result of immigration at the turn of the new millennium.

Beginning in the ' 90 s the natural balance (i.e. the difference between the birth rate and the death rate in the anagraphic registers) of Italian residents began to show a decline not as a result of a rise in mortality rates but due to a lower birth rate. The average number of children born per Italian woman went from 2.34 children in 1952 to 1.19 in 1995 (the lowest rate) and then began to rise again reaching 1.33 in 2004 [3].

Life expectancy at birth has increased by 43 years for men and by 48 years for women in less than 120 years, going from 35.2 years in 1881 to 78.8 years in 2008 for males and from 35.6 to 84.1 years for females [4]. The Italian National Institute of Statistics (ISTAT) estimates that life expectancy at birth will continue to increase arriving in 2050 at 85.3 years for males and approximately 90 for females (central hypothesis; [3]).

The reduction in birth and death rates has caused population age structures to change, as can be seen in the pyramid outlined in Figure 1 (year 2007; forecasts for 2050). The elderly population, defined as those over 65, in 2007 made up $19.9 \%$ of the total population and estimates have indicated that it will surpass $30 \%$ in 2050 . The population of the older old people, or subjects who are 80 or over, will rise from $5.3 \%$ in 2007 to $13.5 \%$ in 2050 .
Life expectancy at birth is an important indicator particularly in demographically young countries. In a progressively ageing society, life expectancy, however, is not an important value in itself as it does not take into account the prevalence increase in chronic, non-communicable degenerative diseases particularly affecting the oldest elderly. Chronic diseases such as high blood pressure, osteoarthritis (arthrosis, arthritis), osteoporosis, diabetes, chronic respiratory diseases, neurological disorders, cardiovascular diseases, and sensory deficits are only a few of the conditions which frequently lead to states of illness and to progressive functional impairment and loss of autonomy. The economic impact of these conditions is important in terms of health care costs for diagnosis, treatment and rehabilitation [5]. But regardless of its cost, maintaining good functional efficiency is essential for the quality of life of elderly persons. Studies on population ageing must also take into consideration indicators measuring time spent free of disability and in good health.

\section{HEALTH EXPECTANCY INDICATORS}

Health expectancy indicators aim to assess life expectancy in particular states of health (in diseased states, in state of disability or in a specific self-perceived health state), combining information on mortality with that of morbidity. The general model of health transitions upon which health expectancies are based were outlined by the WHO in 1984 [6] defining, for the various age groups, the following:

a) residual life expectancy;

b) disability-free life expectancy;

c) life expectancy without chronic disease.

Health expectancy indicators can be utilized to detect differences in health status existing within and between countries making it possible to focalize on policies promoting health, to evaluate the impact of
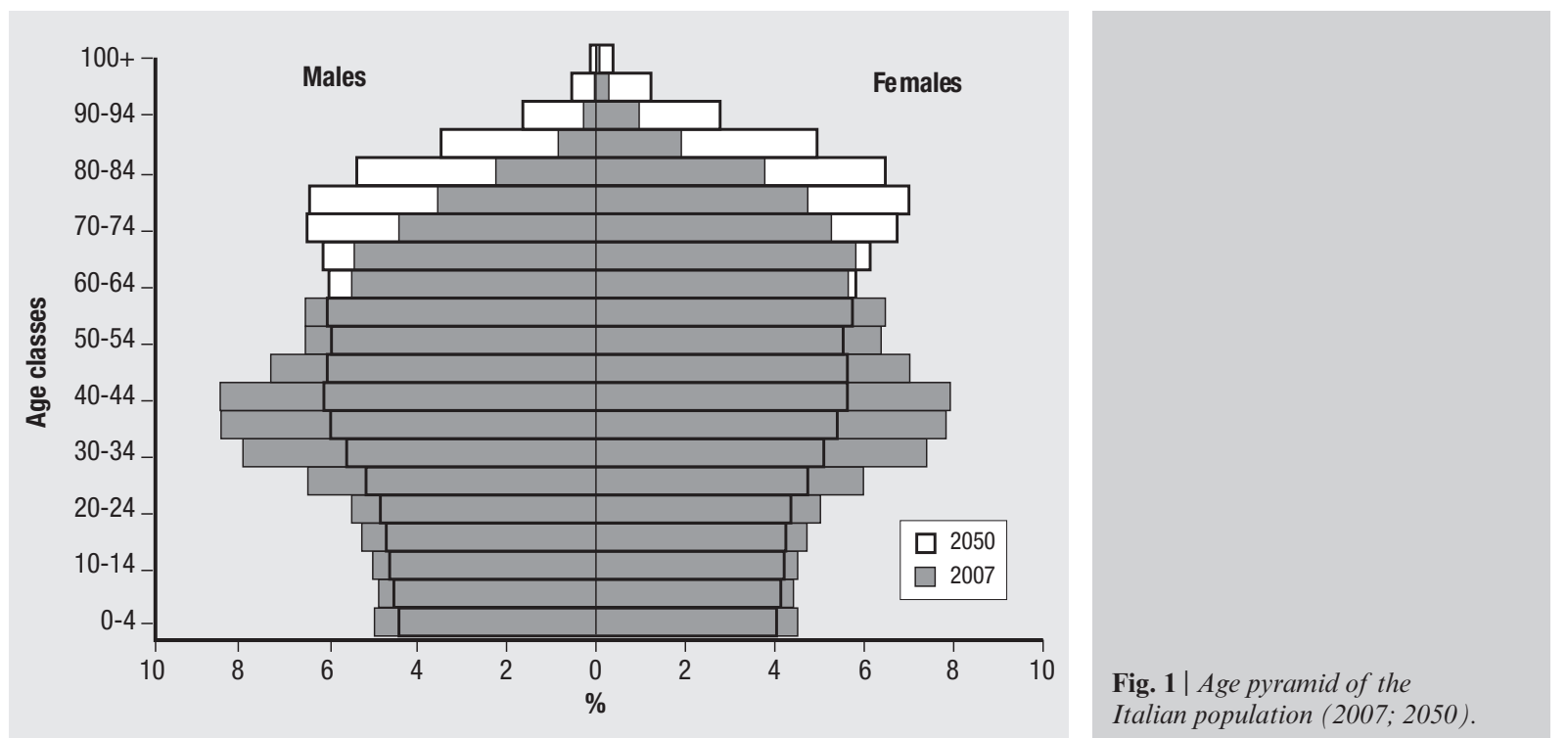
health care planning, and to plan long term social and fiscal strategies. For example, according to some, age at retirement should not be calculated only on the basis of life expectancy but should be assessed in relation to life expectancy without chronic illness, which is an estimation of how many years an individual will be able to work during his/her lifetime.

The European Union has decided to include a set of indicators of health expectancy as a part of the European Community Health Indicators (ECHI) to identify measures of disability, of chronic morbidity and self-perceived health, thus permitting the comparison of health expectancy between countries.

\section{HEALTH EXPECTANCY CALCULATION}

There is more than one method to estimate health expectancy: the differences between the methods regard the type of information that is necessary to make the calculation and the complexity of the calculation methods.

The Sullivan Method [7] utilizes prevalence data on disability or other pathologies with the aim of calculating the number of years lived with and without disability by a hypothetical cohort of subjects based on a mortality table. The data necessary for that calculation is easily attainable, but the method's principal limit is tied to the lack of information on the reversibility of some states of health or disability.

The Multiple Decrement Life Tables Method [8] takes into consideration death and transitions towards other states of health or disability defined $a$ priori as possible events. The model does not foresee the possibility of returning to an initial state: death or disability are seen as absorbing states (i.e. there is no return to the initial status).

The Multistate Life Tables Method [9-11] considers mortality, the incidence of disability or other pathologies, and transitions between states of health in all possible directions as events. Disability and disease are considered temporary, not necessarily irreversible conditions, so incidence rates of disability or disease and remission rates are utilized. This method needs flow data arising from longitudinal studies or register data. Multistate Life Tables are constructed simulating for each age, the probability of onset of disability, healing and/or death and inferring from these the number of person-years lived in disabled conditions.

The Multistate Life Tables Method is considered an important instrument to understand current morbidity and mortality and their future implications on the population's health [12]. Some researchers developed simulations using French data to compare health expectancy calculated utilizing the Sullivan or the Multistate Life Tables [13]. Those researchers arrived at the conclusion that Sullivan's Method is not usable to discern quick changes in transition rates between states of disability, but provides a good estimate of multistate values when those changes are relatively linear and regular over a long time period. The Authors concluded affirming that the Sullivan Method seems to be acceptable to analyze, over a long period, tendencies in health expectancy in non stationary populations.

\section{DISABILITY-FREE LIFE EXPECTANCY}

The disability free life expectancy (DFLE) indicator, probably the most well known measure of health expectancy, is based on the Sullivan Method and measures the number of years that an individual is expected to live free of disability if current patterns of mortality and disability continue to apply. Numerous publications found in PubMed present the results of DFLE calculations focalizing on gender differences [14-20], inequalities in social class defined on the basis of level of education or occupation [16, 20, 21-33] and temporal trends [20, 34-41]. Particular attention should be paid to international comparisons as these may reflect different definitions of disability or scales.

\section{ESTIMATES IN EUROPE}

The European Health Expectancy Monitoring Unit (EHEMU) and the European Health and Life Expectancy Information Systems (EHLEIS), which is the continuation of the former for the years between 2007-2010, have attempted to harmonize the data and analysis techniques utilized to estimate health expectancy in Europe.

The EHEMU elaborated estimates for the DFLE for the period between 1991 and 2003 based on data coming from the European Community Household Panel (ECHP) Investigation. Those first calculations, defined as an exercise because of the limited data considered, show how life expectancy at birth has constantly risen in the period considered with only small variations between countries, while the DFLE shows different trends in the various countries also with regard to gender. The DFLE remains constant in some countries while in others it increases suggesting a compression of disability. It should be remembered that part of the differences in the estimated DFLE are due to the diversity in the method of measuring disability, given also methodological limits and cultural differences that may have an impact on self-reported disability.

The EHEMU has proposed new health expectancy estimates for the European Union for the year 2004 based on data from the SHARE study [42]. The SHARE Study has the advantage of permitting cross-national comparisons with regard to public health policies as well as cultural and historical aspects in different European countries. In 2004, the year of the baseline study, data from 11 European countries were available with regard to physical health and this made it possible to calculate different types of health expectancy as follows:

- life expectancy based on self-perceived health;

- life expectancy without chronic disease; 


\begin{tabular}{|c|c|c|c|c|}
\hline & \multicolumn{4}{|c|}{ Males } \\
\hline & 1994 & 2000 & 2005 & 1994-2005 \\
\hline Life expectancy at 65 years & 15.5 & 16.5 & 17.5 & $+12.9 \%$ \\
\hline Life expectancy in good health status at 65 years & 3.3 & 3.6 & 4.7 & $+42.4 \%$ \\
\hline \multirow[t]{3}{*}{ DFLE at 65 years } & 12.7 & 13.7 & 14.9 & $+17.3 \%$ \\
\hline & \multicolumn{4}{|c|}{ Females } \\
\hline & 1994 & 2000 & 2005 & 1994-2005 \\
\hline Life expectancy at 65 years & 19.4 & 20.4 & 21.3 & $+9.8 \%$ \\
\hline Life expectancy in good health status at 65 years & 3.2 & 3.2 & 4 & $+25.0 \%$ \\
\hline DFLE at 65 years & 14.2 & 15.2 & 16.2 & $+14.1 \%$ \\
\hline
\end{tabular}

- life expectancy without mobility limitations;

- life expectancy without limitations in activities of daily living (ADL);

- life expectancy without instrumental activity restrictions (IADL).

In general, the results show how women live a longer period of their lives with health problems with respect to men. The Netherlands seems to be the country with the best health expectancy. The EHEMU report concludes affirming that it will be interesting to compare the 25 countries belonging to the European Union with regard to responses to the statistics on income and living conditions (SILC) investigation.

The most recent European estimates calculated by EUROSTAT (the agency within the European Union charged with providing statistical information for the continent) for healthy life years referring to 2009 were constructed utilizing information on self-perceived disability. At birth a male subject resident in the 27 member states of the European Union (UE27) can expect to live almost $80 \%$ of his life free of disability, while his female counterpart can expect to live $75.2 \%$ of her life free of disability. There are clear differences between countries: males in Malta, Sweden, Bulgaria, Norway, Iceland, Romania on the average will live more than $85 \%$ of their future life free of disability, while those residing in Germany and Slovakia will live less than $75 \%$ of their future life in that condition. The countries where women's statistics are above the European average (percents above $80 \%$ ) are Malta, Bulgaria, Sweden, Iceland, and Norway, while the percent of their lives that female newborns will live free of disability is $70 \%$ for Slovakia, Portugal, Germany and Finland. Italy, for whom data are available only for 2008, had values that are slightly inferior to the UE27 average both for males and for females. In fact, a male infant born in Italy will live on the average $79 \%$ of his life free of disability and a female newborn will live $72.4 \%$ disability free.

\section{ESTIMATES IN ITALY}

ISTAT furnishes estimates for the DFLE or for life expectancy in good health calculated using the Sullivan Method, utilizing data coming from The Conditions of Health and Recourse to health services part of the Multiaim Investigation of Italian Families. The national and regional estimates that are now available regard 1994, 1999/2000, and 2004/2005 [43].

The Multiaim Investigation of Italian Families furnishes information on the self-perceived state of health, symptoms, chronic conditions, disability, and behaviours that influence the health of the population. It is an investigation conducted by ISTAT on a sample of families living in all regions of the country. The questionnaire was administered to persons of all ages over six years of age with the exclusion of persons permanently living in institutions or other forms of collective cohabitation such as rest homes for the elderly or the disabled. The Multiaim Investigation makes it possible to identify four types of disability: personal confinement (being bedridden or in a wheelchair, or home ridden), disability in activities of daily living, disability in movements (walking, climbing stairs, sitting down, lying down, bending over), sensory disability (difficulty in hearing, seeing or speaking). A person is defined disable if, excluding temporary limitations, he/she declares that he/she is unable to carry out at least one of the functions cited above despite the use of protheses, crutches, glasses, etc. Table 1 summarizes some results relative to the evolution of life expectancy and the DFLE in Italy. Both the life expectancy at 65 and the DFLE as well as the life expectancy in good health have risen in the period considered. In males the gain is higher both in terms of life expectancy at 65 (from 15.5 years in 1994 to 17.5 years in 2005) and life expectancy in good health at 65 (from 3.3 years to 4.7 ) as well as of the DFLE (from 12.7 years to 14.9) with respect to females. Figure 2 outlines the breakdown of life expectancy at 65 in self-reported good/poor health 

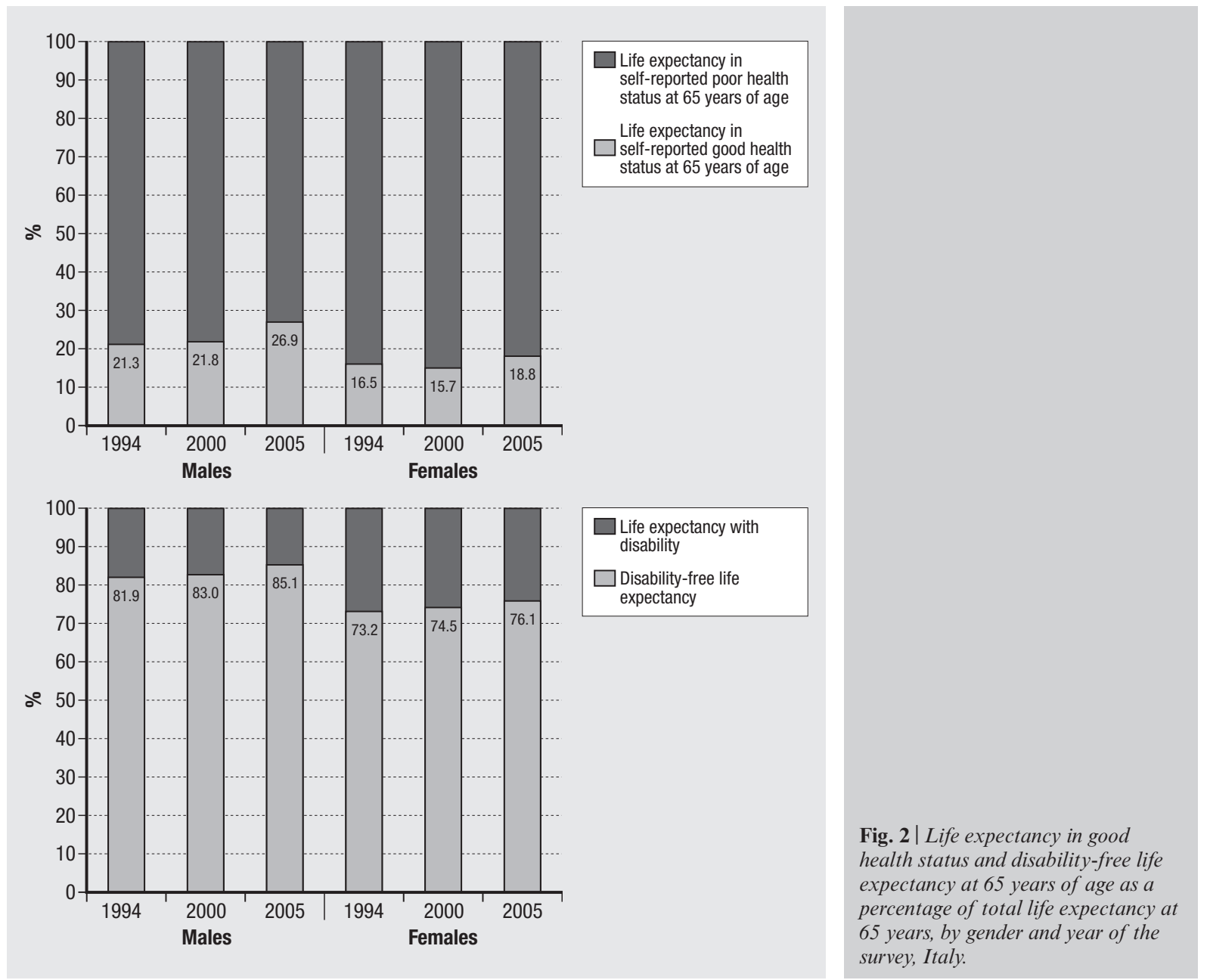

status and in a condition with/without disability, considering 100 the total life expectancy at 65 . The figure permits us to reflect on the fact that males expect to live a higher percentage of their life after 65 in a disability-free condition with respect to females. The advantage of females in terms of overall life duration is, unfortunately, accompanied by a higher percentage of life in a self-reported poor health status.

A recent analysis conducted on data from the Multiaim Investigation broke down the DFLE in relation to contributions of disability and mortality, and illustrated how the gap in the DFLE between males and females is shrinking thanks to the rapid diminution in mortality rates in males [44].

ISTAT has also provided regional estimates of life expectancy and the DFLE. The most recent year for which the estimates are available is 2005 (Table 2). For both sexes the DFLE at 65 is higher in the Northern and Central Regions of Italy. The major part of the regions of the south showed figures that are inferior to the national average and Sicily is the region with the worst figures.

\section{CONCLUSIONS}

In view of the evidence of the progressive ageing of our society some general indicators of mortality such as total life expectancy no longer appear sufficient to provide politicians and health care administrators with the data they need to coordinate and ensure appropriate health care planning. Good health care programs should aim not only to increase the life expectancy of the population but also to guarantee that the years of life gained are years lived in good health conditions, also in light of the WHO declaration affirming that "increased longevity without quality of life is an empty prize. Health expectancy is more important than life expectancy" [45]. It is essential then to study healthy ageing, defined as "the ideal situation in which people survive to an advanced age with their vigour and functional independence intact and with morbidity and disability compressed into a relatively short period before death". While the features of healthy ageing have not yet been clearly defined, some researchers such as those who were involved in the FUTURAGE A road map for ageing Research European Project 
Table $2 \mid$ Life expenctancy and disability-free life expectancy (DFLE) at 65 years, by gender and region. Year 2005, Italy

\begin{tabular}{lcccc} 
& \multicolumn{2}{c}{ Males } & \multicolumn{2}{c}{ Females } \\
& $\begin{array}{c}\text { Life expectancy } \\
\text { at } \mathbf{6 5}\end{array}$ & $\begin{array}{c}\text { DFLE } \\
\text { at } \mathbf{6 5}\end{array}$ & $\begin{array}{c}\text { Life expectancy } \\
\text { at 65 }\end{array}$ & $\begin{array}{c}\text { DFLE } \\
\text { at } \mathbf{6 5}\end{array}$ \\
\hline Piemonte & 17.4 & 14.8 & 21.2 & 16.5 \\
Valle d'Aosta & 17.4 & 15.2 & 21.2 & 16.6 \\
Lombardia & 17.4 & 15.4 & 21.6 & 17.1 \\
Trentino-Alto Adige & 17.9 & 15.7 & 22.0 & 18.5 \\
Veneto & 17.5 & 14.6 & 21.9 & 17.2 \\
Friuli-Venezia Giulia & 17.4 & 15.5 & 21.6 & 16.8 \\
Liguria & 17.6 & 14.8 & 21.6 & 16.6 \\
Emilia-Romagna & 18.0 & 15.9 & 21.8 & 17.2 \\
Toscana & 17.8 & 15.3 & 21.7 & 16.6 \\
Umbria & 17.6 & 15.2 & 21.6 & 15.7 \\
Marche & 18.4 & 15.6 & 22.3 & 16.7 \\
Lazio & 17.3 & 14.8 & 20.9 & 16.1 \\
Abruzzo & 17.6 & 14.7 & 21.6 & 16.2 \\
Molise & 17.6 & 14.4 & 21.6 & 15.6 \\
Campania & 16.5 & 13.8 & 20.0 & 14.8 \\
Puglia & 17.8 & 14.5 & 21.2 & 14.4 \\
Basilicata & 17.6 & 14.5 & 21.1 & 14.9 \\
Calabria & 17.7 & 14.8 & 20.8 & 14.3 \\
Sicilia & 17.2 & 13.7 & 20.3 & 13.4 \\
Sardegna & 17.8 & 14.4 & $\mathbf{1 6 . 1}$ \\
Italy & $\mathbf{1 7 . 5}$ & $\mathbf{1 4 . 9}$ & \\
\end{tabular}

[46] have already begun to address the issue and other studies are being designed.

Epidemiologic data demonstrate that advanced age carries in any population the increasing risk of being stricken by multimorbidity, of becoming disabled, and loss of autonomy [47, 48]. These risks depend on the fact that many diseases characterizing old age are chronic and disabling. The increase in the risk of comorbidity and disability as well as of psychosocial disturbances are characteristic of frailty in the elderly [49]. All of these negative characteristics become evident particularly after 75 and are responsible for the net increase in care needs and thus in socio-health costs connected to that age group [50].

Meeting rising health care costs, which at least in part are attributed to the number of very old elderly, will be a major challenge for future generations. Some important interconnected considerations are:

1) the need to reduce the prevalence of disability in order to bring total life expectancy closer to active life expectancy. This is not only a fundamental indicator of efficacy - attaining the best possible level of quality of life - but also of the efficiency of the heath care system in that a diminution in disability implies a reduction in costs;
2) when the efficacy of the health system is being assessed, it is not sufficient to consider exclusively traditional indicators such as life expectancy or the reduction in the newborn mortality rate. Data on the prevalence of disability in the elderly population and active life expectancy free from disability and thus from burdensome health care needs and resources must be included;

3) the diversity in the DFLE between Northern and the Southern Italy supports the hypothesis that external factors not tied to ageing in itself can determine different levels of disability and thus the care needed by the elderly.

\section{Conflict of interest statement}

There are no potential conflicts of interest or any financial or personal relationships with other people or organizations that could inappropriately bias conduct and findings of this study.

\section{Acknowledgments}

The authors wish to thank Linda Inverso Moretti for reviewing the English version of this manuscript.

Received on 3 March 2012

Accepted on 2 July 2012. 


\section{References}

1. Calot G, Sardon JP. Les facteurs du vieillissement démographique. Population 1999;54:509-52 http://dx.doi.org/10.2307/1534988

2. Stanta G, Brunetti D. Allungamento della vita e modificazioni dei tipi di patologia. Quaderni Europei sul nuovo Welfare, svecchiamento e società 2006;3:118-23.

3. Istituto Nazionale di Statistica (ISTAT). Demography in figures. Available from: http://demo.istat.it/index_e.html . Last visited: $02 / 2012$.

4. Istituto Nazionale di Statistica (ISTAT). Tavole di mortalità multiperiodali. Available from: http://homes.stat.unipd.it/guseo/ tmistat.doc. Last visited: 02/2012.

5. Scafato E, Meli P. La sanità e l'invecchiamento della popolazione. Aggiungere vita agli anni che sono stati aggiunti alla vita. Treccani Sanità. Il libro dell'anno 2001. Available from: www.treccani.it/enciclopedia/sanita_(Il-Libro-dell'Anno)/. Last visited: 02/2012.

6. World Health Organization. The uses of epidemiology in the study of the elderly. Report of a WHO Scientific Group on the epidemiology of aging. (Technical Report Series, 706). Geneva: WHO; 1984.

7. Sullivan DS. A single index of mortality and morbidity. HSMA Health Rep 1971;347-54. http://dx.doi.org/10.2307/4594169

8. Katz S, Branch LG, Branson MH, Pepsidero JA, Beck JC, Greer DS. Active life expectancy. N Engl J Med 1983;309:1218-24. http://dx.doi.org/10.1056/NEJM198311173092005

9. Rogers A, Rogers RG, Belanger A. Longer life but worse health? Measurements and dynamics. Gerontologist 1990;30(5):640-9. http://dx.doi.org/10.1093/geront/30.5.640

10. Rogers A, Rogers RG, Branch LG. A multistate analysis of active life expectancy. Public Health Rep 1989;104:222-5.

11. Rogers RG, Rogers A, Belanger A. Active life among the elderly in the United States. Multistate life-tables estimates and population projections. Milbank Quarterly 1989;67(3-4): 370-411. http://dx.doi.org/10.2307/3350221

12. Cambois E. Overview of the methods of calculation and methodological problems. In: Robine JM, Jagger C, Egidi V. Selection of a coherent set of health indicators. A first step towards a user's guide to health expectancies for the European Union. Montepellier: EuroREVES; 2000.

13. Mathers CD, Robine JM. How good is Sullivan's method for monitoring changes in population health expectancies? J Epidemiol Comm Health 1997;51:80-6. http://dx.doi.org/10.1136/jech.51.1.80

14. Drumond Andrade FC, Guevara PE, Lebrão ML, de Oliveira Duarte YA, Santos JL. Gender differences in life expectancy and disability-free life expectancy among older adults in São Paulo, Brazil. Womens Health Iss 2011;21(1):64-70. http://dx.doi.org/10.1016/j.whi.2010.08.007

15. Baerlocher MO. Differences in healthy life expectancy among men and women. CMAJ 2007;177(10):1174 http://dx.doi.org/10.1503/cmaj.060674

16. Minicuci N, Noale M, ILSA group. Influence of level of education on disability free life expectancy by sex: the ILSA study. Exp Gerontol 2005;40(12):997-1003. http://dx.doi.org/10.1016/j.exger.2005.08.011

17. Chang CF, Nocetti D, Rubin RM. Healthy life expectancy for selected race and gender subgroups: the case of Tennessee. South Med J 2005;98(10):977-84. http://dx.doi.org/10.1097/01.smj.0000182512.68037.0c

18. Mathers CD, Murray CJ, Lopez AD, Sadana R, Salomon JA. Global patterns of healthy life expectancy for older women. $J$ Women Aging 2002;14(1-2):99-117. http://dx.doi.org/10.1300/J074v14n01_07
19. Bélanger A, Martel L, Berthelot JM, Wilkins R. Gender differences in disability-free life expectancy for selected risk factors and chronic conditions in Canada. J Women Ag 2002; 14(1-2):61-83. http://dx.doi.org/10.1300/J074v14n01_05

20. Crimmins EM, Saito Y. Trends in healthy life expectancy in the United States, 1970-1990: gender, racial, and educational differences. Soc Sci Med 2001;52(11):1629-41. http://dx.doi.org/10.1016/S0277-9536(00)00273-2

21. Valkonen T, Sihvonen AP, Lahelma E. Health expectancy by level of education in Finland. Soc Sci Med 1997;44(6):801-8. http://dx.doi.org/10.1016/S0277-9536(96)00190-6

22. Doblhammer G, Kytir J. Social inequalities in disability-free and healthy life expectancy in Austria. Wien Klin Wochensch 1998;110(11):393-6.

23. Cambois E, Robine JM, Hayward MD. Social inequalities in disability-free life expectancy in the French male population, 1980-1991. Demography 2001;38(4):513-24. http://dx.doi.org/10.1353/dem.2001.0033

24. Nusselder WJ, Looman CW, Mackenbach JP, Huisman M, van Oyen H, Deboosere P, Gadeyne S, Kunst AE. The contribution of specific diseases to educational disparities in disability-free life expectancy. Am J Public Health 2005;95(11):2035-41. http://dx.doi.org/10.2105/AJPH.2004.054700

25. Matthews RJ, Jagger C, Hancock RM. Does socio-economic advantage lead to a longer, healthier old age? Soc Sci Med 2006;62(10):2489-99. http://dx.doi.org/10.1016/j.socscimed.2005.11.019

26. Wood R, Sutton M, Clark D, McKeon A, Bain M. Measuring inequalities in health: the case for healthy life expectancy. $J$ Epidemiol Comm Health 2006;60(12):1089-92. http://dx.doi.org/10.1136/jech.2005.044941

27. Jagger C, Matthews R, Melzer D, Matthews F, Brayne C. MRC CFAS. Educational differences in the dynamics of disability incidence, recovery and mortality. Findings from the MRC Cognitive Function and Ageing Study (MRC CFAS). Int J Epidemiol 2007;36(2):358-65. http://dx.doi.org/10.1093/ije/dyl307

28. Pampalon R, Hamel D, Gamache P. A comparison of individual and area-based socio-economic data for monitoring social inequalities in health. Health Rep 2009;20(4):85-94.

29. Smith MP, Olatunde O, White C. Inequalities in disabilityfree life expectancy by area deprivation: England, 2001-04 and 2005-08. Health Stat $O$ 2010;(48):36-57. http://dx.doi.org/10.1057/hsq.2010.20

30. White C, Edgar G. Inequalities in disability-free life expectancy by social class and area type: England, 2001-03. Health Stat $Q 2010 ;(45): 57-80$. http://dx.doi.org/10.1057/hsq.2010.4

31. Szwarcwald CL, da Mota JC, Damacena GN, Pereira TG. Health inequalities in Rio de Janeiro, Brazil: lower healthy life expectancy in socioeconomically disadvantaged areas. Am J Public Health 2011;101(3):517-23. http://dx.doi.org/10.2105/AJPH.2010.195453

32. Smith MP, Olatunde O, White C. Disability-free life expectancy: comparison of sources and small area estimates in England, 2006-08. Health Stat Q 2011;(50):40-78. http://dx.doi.org/10.1057/hsq.2011.8

33. Majer IM, Nusselder WJ, Mackenbach JP, Kunst AE. Socioeconomic inequalities in life and health expectancies around official retirement age in 10 Western-European countries. J Epidemiol Comm Health 2011;65(11):972-9. http://dx.doi.org/10.1136/jech.2010.111492

34. Cambois E, Robine JM. An international comparison of trends in disability-free life expectancy. Dev Health Econ Publ Pol 1996;5:11-23. 
35. Doblhammer G, Kytir J. Compression or expansion of morbidity? Trends in healthy-life expectancy in the elderly Austrian population between 1978 and 1998. Soc Sci Med 2001;52(3):385-91. http://dx.doi.org/10.1016/S0277-9536(00)00141-6

36. Perenboom RJ, Van Herten LM, Boshuizen HC, Van Den Bos GA. Trends in disability-free life expectancy. Disabil Rehabil 2004;26(7):377-86. http://dx.doi.org/10.1080/0963828032000174098

37. Sagardui-Villamor J, Guallar-Castillón P, García-Ferruelo M, Banegas JR, Rodríguez-Artalejo F. Trends in disability and disability-free life expectancy among elderly people in Spain: 19861999. J Gerontol A Biol Sci Med Sci 2005;60(8):1028-34. http://dx.doi.org/10.1093/gerona/60.8.1028

38. Liu J, Chen G, Song X, Chi I, Zheng X. Trends in disability-free life expectancy among Chinese older adults. J Aging Health 2009;21(2):266-85. http://dx.doi.org/10.1177/0898264308328978

39. Crimmins EM, Hayward MD, Hagedorn A, Saito Y, Brouard N. Change in disability-free life expectancy for Americans 70-years-old and older. Demography 2009;46(3):627-46.

40. Hashimoto S, Kawado M, Seko R, Murakami Y, Hayashi M, Kato M, Noda T, Ojima T, Nagai M, Tsuji I. Trends in disability-free life expectancy in Japan, 1995-2004. J Epidemiol 2010;20(4):308-12. http://dx.doi.org/10.2188/jea.JE20090190

41. Cheung KS, Yip PS. Trends in healthy life expectancy in Hong Kong SAR 1996-2008. Eur J Ageing 2010;7(4):257-69. http://dx.doi.org/10.1007/s10433-010-0171-3

42. European Health Expectancy Monitoring Unit. Estimations of health expectancy at age 65 in European Union countries in
2004. Calculations based on data from SHARE 2004 - June 2006. (EHEMU Technical Report 2006_2).

43. Istituto Nazionale di Statistica. ISTAT HFA 2011. Available from: http://www.istat.it/it/archivio/14562. Last visited: 02/2012.

44. Frova L, Burgio A, Battisti A. Are gaps in disability free life expectancies diminishing in Italy? Eur J Ageing 2010:7;239-47. http://dx.doi.org/10.1007/s10433-010-0173-1

45. World Health Organisation. World Health Report 1997. Geneva, Switzerland: WHO; 1997.

46. Jagger C, Parker, S, Avlund K, Hendriksen C, McKee K. "Healthy Ageing Work" Package 5. Final report from two Scientific Workshops held in Newcastle upon Tyne (UK) on 15-16 March 2010 and 12-13 July 2010. Futurage a road map for ageing research; October 2010

47. Fried LP, Guralnik JM. Disability in older adults: evidence regarding significance, etiology, and risk. J Am Geriatr Soc 1997; 45(1):92-100.

48. Fried LP, Bandeen-Roche K, Kasper JD, Guralnik JM Association of comorbidity with disability in older women: the women's health and aging study. Clin Epidemiol 1999; 52(1):27-37. http://dx.doi.org/10.1016/S0895-4356(98)00124-3

49. Topinková E. Aging, disability and frailty. Ann Nutr Metab 2008;52(Suppl. 1):6-11. http://dx.doi.org/10.1159/000115340

50. Romanto G, Rebba VS, Weber G, Zambon S, Corti MC, Baggio G, Sartori L, Manzato E, Crepaldi G. An evaluation of the costs of disability in the elderly based on the Pro.V.A. (Progetto Veneto Anziani) Study. G Gerontol 2005;LIII:633-45. 